\title{
PERBEDAAN KECERDASAN EMOSIONAL SISWA DITINJAU DARI JENIS KEGIATAN EXTRAKURIKULER
}

\author{
Vety Dazeva \\ Tarmidi $^{*}$ \\ ABSTRACT
}

Tujuan penelitian ini adalah untuk melihat perbedaan kecerdasan emosional ditinjau dari jenis kegiatan ekstrakurikuler yang diikuti siswa SMA. Kecerdasan emosional terdiri dari aspek kemampuan mengenali emosi diri sendiri, kemampuan mengelola emosi diri, kemampuan memotivasi diri sendiri, kemampuan mengenali emosi orang lain, dan kemampuan membina hubungan (Goleman, 2002). Kegiatan ekstrakurikuler dibagi menjadi 5 jenis, yaitu keterlibatan prososial, tim olahraga, pertunjukan seni, keterlibatan sekolah, dan kelompok akademik. Partisipan dalam penelitian ini adalah siswa SMA Swasta Yapena yang aktif mengikuti kegiatan ekstrakurikuler yaitu sebanyak 163 siswa. Hasil penelitian menunjukkan terdapat perbedaan kecerdasan emosional ditinjau dari jenis kegiatan ekstrakurikuler yang diikuti siswa SMA Swasta YAPENA.

Kata kunci: Kecerdasan emosional; kegiatan ekstrakurikuler

\section{DIFFERENCES STUDENT'S EMOTIONAL INTELLIGENCE SEEN FROM EXTRACURRICULAR ACTIVITIES TYPE}

\begin{abstract}
The purpose of this study was to examine the differences in emotional intelligence in terms of types of extracurricular activities that followed SMA Swasta YAPENA students. According to Goleman (2002) emotional intelligence consists of the ability to recognize the emotional aspects of self, emotional self-management capabilities, ability to motivate themselves, ability to recognize the emotions of others, and ability to build relationships. of extracurricular activities are divided into 5 types, prosocial activity, team sports, performing arts, school involvement, and academic groups. Participants students of SMA Swasta YAPENA that active in participating in extracurricular activities is as much as 163 students. The results showed that that there were significant differences in emotional intelligence in terms of types of extracurricular activities followed by SMA YAPENA students.
\end{abstract}

Key words: Emotional intelligence; extracurricular activities

\footnotetext{
* Korespondensi mengenai penelitian ini dapat dilayangkan kepada Tarmidi, melalui e-mail: bro.midi@gmail.com
} 
Selain untuk mengembangkan kemampuan inteligensi (IQ), pendidikan juga perlu mengembangkan Emotional Intelligence (EI) siswa di mana keseimbangan antara IQ dan EI merupakan kunci keberhasilan siswa di sekolah. Studi yang dilakukan oleh Widyasari (2008) pada SMA di Surakarta menunjukkan bahwa kurikulum pendidikan nasional di Indonesia saat ini lebih banyak bobot pendidikannya yang diarahkan untuk merangsang perkembangan kognitif siswa dan kurang diimbangi oleh stimulasi bagi perkembangan aspek sosial dan emosi. Perhatian terhadap EI masih sangat kurang. Padahal menurut Goleman (2002) kecerdasan intelektual (IQ) hanya menyumbang $20 \%$ bagi kesuksesan, sedangkan $80 \%$ lainnya adalah sumbangan faktor kekuatan-kekuatan yang lain, di antaranya adalah kecerdasan emosional atau Emotional Intelligence (EI), yakni kemampuan memotivasi diri sendiri, mengatasi frustasi, mengontrol desakan hati, mengatur suasana hati (mood), berempati serta kemampuan bekerja sama.

Menurut Goleman (2002) kecerdasan emosional merupakan kemampuan seseorang mengatur kehidupan emosinya dengan inteligensi (to manage our emotional life with intellegence), menjaga keselarasan emosi dan mengungkapkannya (the appropriateness of emotion and its expression) melalui keterampilan kesadaran diri, pengendalian diri, motivasi diri, empati, dan keterampilan sosial. Apabila seseorang memiliki IQ tinggi namun taraf kecerdasan emosionalnya rendah maka cenderung akan terlihat sebagai orang yang keras kepala, sulit bergaul, mudah frustasi, tidak mudah percaya pada orang lain, tidak peka dengan kondisi lingkungan dan cenderung putus asa bila mengalamai stress. Kondisi sebaliknya, dialami oleh orang-orang yang memiliki taraf IQ rata-rata namun memiliki kecerdasan emosional tinggi. Siswa yang memiliki IQ tinggi cenderung lebih tertutup dengan lingkungan sekitar dan kurang bisa menerima perbedaan. Menurut Fernandez (2008) hal ini terjadi karena kurang berkembangnya kecerdasan emosional yang dapat menyebabkan siswa kurang bisa mengembangkan keterampilan kesadaran diri, pengendalian diri, motivasi diri, empati dan keterampilan sosial mengontrol diri. Tidak heran bila saat ini banyak anak yang pandai secara intelektual, tetapi gagal secara emosional.

Pada dasarnya kecerdasan emosional dapat diasah dengan mengikuti kegiatan-kegiatan yang positif. Menurut Hapsari (2010) kegiatan di masa remaja sering hanya berkisar pada kegiatan sekolah dan seputar usaha menyelesaikan urusan di rumah, selain urusan tersebut remaja memiliki banyak waktu luang. Waktu luang tanpa kegiatan yang berarti akan menimbulkan gagasan untuk mengisi waktu luang dengan berbagai bentuk kegiatan. Apabila remaja melakukan kegiatan yang positif, tentu tidak akan menimbulkan masalah. Namun, jika waktu luang tersebut digunakan untuk melakukan kegiatan yang negatif maka lingkungan dapat terganggu. Maryati (2008) menyatakan bahwa pengisian waktu luang yang baik dengan cara menyesuaikan dengan umur remaja, masih merupakan masalah bagi kebanyakan remaja. Kebosanan dan perasaan enggan untuk melakukan apa saja merupakan fenomena yang sering dijumpai. Penelitian yang dilakukan oleh Mahoney (2006) pada siswa-siswa di Amerika menunjukkan hasil bahwa siswa yang dapat memanfaatkan waktu luangnya dengan hal-hal positif antara sepuluh sampai dua puluh jam setiap minggu, memiliki kecerdasan emosional yang positif serta terhindar dari ancaman kenakalan remaja seperti penggunaan rokok, ganja, dan alkohol.

Sekolah sebagai instansi yang selama ini dipercaya untuk mendidik anak-anak dan remaja dapat mengambil peran membantu remaja mengisi waktu luangnya dengan kegiatan positif. Sekolah dapat memfasilitasi dengan mengaktifkan kegiatan ekstrakurikuler di sekolah sehingga setelah jam sekolah usai siswa terhindar dari melakukan aktivitas yang mengarah pada kenakalan. Sekolah perlu memberikan kesempatan melaksanakan kegiatan-kegiatan 
nonakademik melalui perkumpulan penggemar olahraga, kesenian, dan lainnya untuk membantu remaja menyelesaikan tugas perkembangannya. Kegiatan ekstrakurikuler adalah kegiatan yang diadakan di luar jam sekolah yang dimaksudkan untuk lebih memantapkan pembentukan kepribadian, dan untuk lebih mengaitkan antara pengetahuan yang diperoleh dalam program kurikulum dan keadaan serta kebutuhan lingkungan (Sudjana, 2002).

Kegiatan ekstrakurikuler bermakna untuk memperluas pengetahuan siswa. Dalam arti memperkaya, mempertajam, serta memperbaiki pengetahuan para siswa yang berkaitan dengan mata pelajaran sesuai dengan program kurikulum yang ada. Adapun tujuan yang hendak dicapai dengan mengembangkan kegiatan ekstrakurikuler antara lain mengembangkan siswa untuk menjadi manusia yang beriman dan bertaqwa kepada Tuhan Yang Maha Esa, berbudi pekerti luhur, memiliki pengetahuan dan ketrampilan, sehat jasmani dan rohani, berkepribadian yang mantap dan mandiri serta memiliki rasa tanggung jawab kemasyarakatan dan kebangsaan. Dengan melihat tujuan tersebut, tentunya diperlukan suatu proses pendidikan di sekolah yang bisa mengembangkan semua aspek yang diperlukan bagi siswa (Depdiknas, 2005).

Menurut Nurdin (2009) pengembangan potensi siswa tidak hanya dapat dikembangkan hanya melalui pendidikan intrakurikuler, namun pendidikan melalui kegiatan ekstrakurikuler pun memiliki peranan yang besar pula, baik ekstrakurikuler yang bersifat ilmiah, keolahragaan, nasionalisme, maupun keterampilan. Berkembangnya kegiatan ekstrakurikuler yang penuh prestasi, bisa dijadikan suatu kebanggaan bagi sekolah itu sendiri, lebih jauh lagi masyarakat bisa menilai majunya suatu sekolah tidak hanya berdasarkan prestasi akademiknya, melainkan juga prestasi non akademik yang dikembangkan melalui kegiatan ekstrakurikuler. Bakat dan minat terhadap suatu kegiatan yang diprogramkan dalam kegiatan ekstrakurikuler diharapakan dapat tersalurkan, sehingga potensi anak didik dapat dikembangkan secara maksimal. Kegiatan ekstrakurikuler yang terprogram dapat memberi nilai positif bagi siswa dalam memanfaatkan waktu luang. Hal ini didukung oleh penelitian yang dilakukan oleh Cahyaningtyas (2010) bahwa siswa yang ikut serta dalam kegiatan ekstrakurikuler memiliki kecerdasan emosional yang lebih tinggi dibandingkan dengan siswa yang tidak ikut serta dalam kegiatan ekstrakurikuler. Penelitian yang dilakukan oleh Fujita (2005) pada siswa-siswa Walnut Creek Christian Academy di California juga menunjukkan hasil bahwa berpartisipasi dalam kegiatan ekstrakurikuler memiliki pengaruh positif pada prestasi akademik siswa di sekolah.

Menurut Diastuti (2006) kegiatan ekstrakurikuler dapat mencegah siswa melakukan tindakan yang menjurus kepada hal-hal yang negatif. Aktif dalam kegiatan ekstrakurikuler dapat memperkecil peluang siswa untuk bergabung dengan teman-teman sebaya yang melakukan aktivitas negatif. Setelah pulang sekolah atau waktu liburan, remaja menghabiskan waktu di sekolah bersama dengan kelompok teman sebaya yang dibimbing oleh guru pembina ekstrakurikuler. Melalui kegiatan ekstrakurikuler, siswa diajarkan keterampilan teknis, disiplin, kerjasama, kepemimpinan dan nilai-nilai lain yang bermanfaat bagi perkembangan remaja. Hal ini didukung oleh penelitian Rubin (2002) yang menunjukkan hasil bahwa keterlibatan dalam aktivitas ekstrakurikuler dapat meningkatkan empat hal yaitu keterampilan interpersonal, keterampilan kerja tim, pengambilan keputusan, dan inisiatif. Sedangkan hasil penelitian Ashron (2009) menyatakan siswa yang terlibat dalam kegiatan ekstrakurikuler mempunyai sifat dorongan berprestasi yang tinggi, kemampuan bersaing, kemampuan beradaptasi, dan disiplin yang tinggi.

Kegiatan ekstrakurikuler ditujukan untuk pengembangan kreativitas peserta didik. Pengembangan kreativitas dimaksudkan untuk menumbuhkan kemampuan untuk mencipta melalui berbagai kegiatan sesuai dengan kebutuhan, potensi, bakat dan minat secara optimal, 
serta tumbuhnya kemandirian dan kebahagiaan yang berguna untuk diri sendiri, keluarga dan masyarakat (Mahoney, 2005).

Menurut Hapsari (2010) kegiatan ekstrakurikuler dapat meningkatkan keterampilan interpersonal remaja. Melalui kegiatan ekstrakurikuler remaja menjalin hubungan interpersonal dengan teman sebaya anggota ekstrakurikuler yang diikuti, senior dan pembina ekstrakurikuler. Remaja yang memiliki kompetensi interpersonal rendah, afiliasi dengan peer dalam kegiatan ekstrakurikuler dapat meningkatkan penerimaan sosial dan popularitas, menurunkan alienasi sosial, mengembangkan identitas sosial, dan menurunkan perilaku antisosial. Hal ini didukung oleh penelitian Rubin (2002) yang menunjukkan hasil bahwa keterlibatan siswa dalam aktivitas ekstrakurikuler dapat meningkatkan keterampilan interpersonal menjadi lebih baik.

Pada umumnya sekolah menyediakan banyak jenis pilihan ekstrakurikuler kepada siswa. Berdasarkan Departemen Pendidikan Nasional (2003), jenis kegiatan ekstrakurikuler yang harus disediakan pihak sekolah pada siswanya antara lain adalah bidang Kepemimpinan (meliputi Kepramukaan, Latihan Dasar Kepemimpinan Siswa, Palang Merah Remaja, Pasukan Pengibar Bendera Pusaka), bidang Karya Ilmiah (meliputi Kegiatan Ilmiah Remaja, kegiatan penguasaan keilmuan dan kemampuan akademik), Latihan/lomba keberbakatan/prestasi (meliputi pengembangan bakat olah raga, seni dan budaya, cinta alam, keagamaan), dan Kegiatan lapangan (meliputi kegiatan yang dilakukan di luar sekolah berupa kunjungan ke obyek-obyek tertentu). Sedangkan Mahoney (2005) membagi kegiatan ekstrakurikuler menjadi lima jenis yaitu keterlibatan prososial (prosocial activities), tim olahraga (team sports), pertunjukan seni (performing arts), keterlibatan sekolah (school involvement), dan kelompok akademik (academic clubs).

Menurut Hapsari (2010) apabila kegiatan ekstrakurikuler berada dibawah bimbingan yang tepat, kegiatan ekstrakurikuler bisa menjadi wadah yang tepat bagi para siswa dalam mengembangkan bakat dan kemampuannya. Akan tetapi setiap jenis kegiatan ekstrakurikuler mempunyai visi, misi, dan cara yang berbeda dalam membina para siswanya. Menurut Mahoney (2005) hal ini dapat menyebabkan terjadinya perbedaan keterampilan pada suatu jenis ekstrakurikuler dengan jenis ekstrakurikuler lainnya sehingga menimbulkan perbedaan pada kesadaran diri, pengendalian diri, motivasi diri, empati dan keterampilan sosial siswa untuk mengontrol dirinya. Perbedaan ini juga menyebabkan kecerdasan emosional yang terbentuk pada siswa menjadi berbeda.

Mahoney (2005) menyatakan bahwa kegiatan ekstrakurikuler keterlibatan prososial lebih bertujuan untuk meningkatkan kemampuan kepemimpinan, mengembangkan kecerdasan emosional dan kecerdasan spiritual untuk menciptakan lingkungan yang efektif, harmonis terhadap diri sendiri dan terhadap semua pihak. Kegiatan ini dimaksudkan agar siswa terbiasa berinteraksi dan saling kerjasama dengan orang lain. Selain itu kegiatan terebut dapat menumbuhkan kecerdasan emosi siswa karena dengan kegiatan tersebut anak akan menghargai orang lain, belajar mengendalikan emosi, berempati dengan orang lain, saling tolong menolong dan bekerjasama dalam mengerjakan tugas. Hasil penelitian Deniz (2008) yang dilakukan pada siswa di Turki menunjukkan hasil bahwa siswa yang mengikuti Kepanduan/Pramuka memiliki kompetensi kecerdasan emosional yang baik pada kesadaran diri, kemampuan mengatasi masalah, dan belajar berperilaku empatik.

Menurut Brooks (2000) siswa yang mengikuti ekstrakurikuler olahraga tidak hanya dapat mengembangkan keterampilan, tetapi mereka juga belajar untuk menghormati otoritas, belajar untuk menghadapi tantangan baru, dan menikmati kebersamaan dengan teman. Kegiatan olahraga tidak hanya baik untuk fisik tetapi juga meningkatkan emosional siswa. Berolahraga 
dapat mengurangi kecemasan dan depresi, melancarkan peredarahan darah, dan meningkatkan harga diri. Anak-anak yang berolahraga lebih percaya diri, mengurangi ketidakhadiran di sekolah, dan biasanya mendapatkan nilai yang lebih baik. Hasil penelitian Blomfield (2010) yang dilakukan pada siswa-siswa di Australia menunjukkan bahwa keterlibatan dalam kegiatan ekstrakurikuler olahraga mengurangi tingkat penggunaan alkohol, mengurangi ketidakhadiran di sekolah, dan meningkatkan rasa kepemilikan terhadap sekolahnya. Hasil penelitian Ashron (2009) menambahkan bahwa siswa yang terlibat dalam kegiatan ekstrakurikuler olahraga mempunyai semangat kompetisi yang baik.

Berbeda dengan siswa yang mengikuti kegiatan ekstrakurikuler kesenian. Menurut Brooks (2000) siswa yang mengikuti kegiatan ekstrakurikuler kesenian belajar tentang komunikasi. Mereka mempunyai cara yang unik untuk mengekspresikan diri. Ketika anak-anak terlibat dalam seni mereka menjadi lebih kreatif dan imajinatif, mengembangkan keterampilan yang membuat mereka merasa mampu, dan belajar untuk mengembangkan kemampuan berbicara dan menulis. Keterlibatan dalam seni tidak hanya membawa peningkatan kesadaran dan apresiasi saja, tetapi memperluas pemahaman siswa tentang diri mereka sendiri dan orang lain, belajar memecahkan masalah, kemampuan untuk membuat keputusan, dan mengekspresikan diri. Menurut Yue (2009) ekstrakurikuler seni berpengaruh pada siswa untuk mengembangkan bakat artistik serta keterampilan seperti penafsiran, komunikasi dan perhitungan. Hasil penelitian yang dilakukan Sanchezruiz (2010) menyatakan bahwa kelompok seni memiliki emosional, kemampuan bersosialisasi, kesejahteraan, dan kontrol diri yang baik.

Menurut Mahoney (2005) jenis ekstrakurikuler keterlibatan sekolah seperti kegiatan Organisasi Siswa Intra Sekolah (OSIS) memiliki manfaat meningkatkan kepribadian dan budi pekerti, meningkatkan kemampuan berorganisasi, pendidikan politik dan kepemimpinan, meningkatkan keterampilan, kemandirian dan percaya diri, meningkatkan kesehatan jasmani dan rohani, serta mampu menghargai dan menjiwai nilai-nilai seni, meningkatkan dan mengembangkan kreatifitas. Dari hasil penelitian Ashron (2009) menyatakan bahwa siswa yang banyak terlibat dalam kegiatan pemerintahan sekolah mempunyai jiwa kepemimpinan yang tinggi dan juga mempunyai sifat kompetitif.

Pada kegiatan ekstrakurikuler kelompok akademik, menurut Fruh (2005) tujuan yang hendak dicapai adalah pengembangan sikap ilmiah, kejujuran dalam memecahkan gejala alam maupun sosial yang ditemui dengan kepekaan yang tinggi dengan metode yang sistematis, objektif, rasional dan berprosedur sehingga akan didapatkan kompetensi untuk mengembangkan diri dalam kehidupan. Hasil penelitian yang dilakukan oleh Ashron (2009) menyatakan bahwa siswa yang terlibat dalam kegiatan ekstrakurikuler akademik memiliki prestasi akademik yang baik di sekolah dan juga memiliki keterampilan memecahkan masalah yang baik.

SMA Swasta Yayasan Pendidikan Arun (YAPENA) merupakan salah satu sekolah unggul di Propinsi Aceh yang terletak di Kota Lhokseumawe. Prestasi yang dicapai siswa di SMA Swasta YAPENA cukup banyak, baik dalam hal akademik maupun dari kegiatan ekstrakurikuler. Kegiatan ekstrakurikuler di SMA Swasta YAPENA diadakan setiap hari Jumat dan Sabtu yang dimulai dari pukul 15.00 WIB sampai dengan 18.00 WIB. Kegiatan ekrakurikuler yang disediakan antara lain adalah Palang Merah Remaja (PMR), Pramuka, Drumband, Olimpiade, Basket, dan Tenis lapangan. Dalam komunikasi personal yang dilakukan pada tanggal 11 Oktober 2010, Kepala Sekolah SMA Swasta YAPENA mengungkapkan bahwa banyak prestasi yang dihasilkan dari kegiatan ekstrakurikuler di sekolah ini dan sering menjuarai untuk tingkat Pemerintah Kota Lhokseumawe, tingkat Propinsi Aceh, bahkan tingkat Nasional. Untuk ekstrakurikuler Drumband pernah menjadi juara Nasional pada tahun 2006, 
ekstrakurikuler olimpiade pernah mendapatkan peringkat II dan III se-Indonesia pada tahun 2010 serta juara I, II, dan III setiap tahunnya untuk tingkat pemerintahan kota, dan masih banyak lagi prestasi lainnya. Kegiatan ini diharapkan dapat mengembangkan minat dan bakat para siswanya sehingga dapat mencerdaskan emosional para siswa. Dengan adanya kegiatan tersebut, kegiatan belajar-mengajar juga dapat lebih baik dan menambah wawasan siswa. Manfaat kegiatan ekstrakurikuler itu banyak sekali. Siswa mendapatkan beragam hal positif, baik dari sisi keilmuan maupun aspek psikologis dan sosial setiap siswa. Dalam setiap kegiatan ekstrakurikuler yang dipilih tentu ada dasar-dasar ilmunya. Bila berada di bawah bimbingan guru yang tepat, kegiatan ekstrakurikuler bisa menjadi wadah yang tepat bagi para siswa dalam mengembangkan bakat dan kemampuannya. Melalui ekstrakurikuler para siswa bisa memupuk jiwa sportif dalam aneka perlombaan, baik yang digelar secara internal di sekolah maupun eksternal dengan sekolah lain. Ekstrakurikuler juga bisa mengajarkan siswa tentang arti organisasi, walaupun dalam skala yang kecil. Anak bisa belajar menjadi pemimpin, pengurus, atau bahkan belajar mengemas suatu acara yang menarik dalam suatu pameran ekstrakurikuler dan banyak lagi hal positif yang dapat diperoleh siswa.

Setiap jenis kegiatan ekstrakurikuler menunjukkan hasil yang berbeda pada kecerdasan emosionalnya yang terlihat dari perilaku siswa-siswanya. Dalam komunikasi personal yang dilakukan pada tanggal 11 Oktober 2010, Wakil Kepala Sekolah Bidang Kesiswaan SMA Swasta YAPENA mengungkapkan bahwa keragaman jenis ekstrakurikuler juga memberikan keragaman pada sifat dan perilaku siswa. Misalnya, siswa yang ikut dalam kegiatan ekstrakurikuler Pramuka dan PMR mempunyai sifat sosial yang tinggi dalam berhubungan dengan orang lain, sedangkan siswa yang ikut dalam kegiatan ekstrakurikuler Drum Band lebih terkontrol dalam melakukan suatu hal dan juga memiliki keyakinan keberhasilan yang lebih tinggi. Terdapat juga perbedaan antara jenis kegiatan ekstrakurikuler olahraga dengan jenis kegiatan ekstrakurikuler dalam bidang akademik. Siswa yang mengikuti ekstrakurikuler olahraga terlihat lebih dapat bekerjasama dalam kelompok, sedangkan siswa yang mengikuti ekstrakurikuler dalam bidang akademik kurang dapat menjalin kerja sama dengan orang lain, tetapi mempunyai dorongan berprestasi yang tinggi.

Berdasarkan hal-hal tersebut di atas, menyebabkan adanya tingkat perbedaan kecerdasan emosional siswa pada masing-masing jenis kegiatan ekstrakurikuler. Dalam kaitan pentingnya kegiatan ekstrakurikuler untuk meningkatkan kecerdasan emosional pada diri siswa, penulis berminat untuk meneliti lebih mendalam mengenai perbedaan kecerdasan emosional ditinjau dari jenis kegiatan ekstrakurikuler yang diikuti siswa SMA Swasta YAPENA.

\section{METODE}

\section{Partisipan}

Partisipan merupakan 163 orang siswa SMA Yapena yang aktif mengikuti kegiatan ekstrakurikuler. Mereka kami rekruit secara insidental, yaitu kami merekruit mereka yang bersedia untuk berpartisipasi di dalam penelitian ini. Atas partisipasinya, partisipan diberikan reward bolpoin.

\section{Variabel penelitian}

\section{Kecerdasan emosional}

Kecerdasan emosional adalah kemampuan seseorang untuk memantau dan mengendalikan perasaan sendiri dan orang lain, serta menggunakan perasaan-perasaan itu untuk memandu pikiran dan tindakan ke arah yang positif. Kecerdasan emosional kami ukur dengan 
menggunakan skala berdasarkan aspek-aspek kecerdasan emosional menurut Goleman (2002) yang meliputi: mengenali emosi diri, mengelola emosi, memotivasi diri sendiri, mengenali emosi orang lain, dan membina hubungan.

\section{Jenis kegiatan ekstrakurikuler}

Jenis kegiatan ekstrakurikuler yang digunakan dalam penelitian ini dibagi lima berdasarkan jenis kegiatan ekstrakurikuler yang dikemukakan oleh Mahoney (2005) yaitu jenis ekstrakurikuler keterlibatan prososial (prosocial activities) meliputi Pramuka dan PMR, jenis ekstrakurikuler tim olahraga (team sports) meliputi olahraga tenis dan basket, jenis ekstrakurikuler pertunjukan seni (performing arts) meliputi Drum Band, jenis ekstrakurikuler keterlibatan sekolah (school involvement) meliputi OSIS, dan jenis ekstrakurikuler kelompok akademik (academic clubs) yang meliputi International Mathematic Olympiade, International Chemical Olympiade, International Physics Olympiade, International Biology Olympiade, International Olympiade Informatics, Olimpiade Ekonomi, dan Olimpiade Geologi.

\section{Prosedur}

Dalam penelitian ini penulis akan menggunakan skala kecerdasan emosional. Skala kecerdasan emosional terdiri dari aspek mengenali emosi diri, mengelola emosi diri, memotivasi diri sendiri, mengenali emosi orang lain, bekerjasama dengan orang lain (Goleman, 2002).

Masing-masing pernyataan terdiri dari lima alternatif jawaban, yaitu sangat sesuai (SS), Sesuai (S), Netral (N), Tidak Sesuai (TS), dan Sangat Tidak Sesuai (STS). Bobot penilaian skala ini disajikan dalam bentuk pernyataan favourable, yaitu $\mathrm{SS}=4, \mathrm{~S}=3, \mathrm{~N}=2$, $\mathrm{TS}=1$, dan $\mathrm{STS}=0$. Sedangkan bobot penilaian untuk pernyataan unfavourable, yaitu $\mathrm{STS}=4, \mathrm{TS}=3, \mathrm{~N}=2, \mathrm{~S}=1$, dan SS = 0.

\section{Metode analisa data}

\section{Reliabilitas}

Pengujian reliabilitas pada penelitian ini dilakukan dengan menggunakan Koefisien Reliabilitas Alpha Cronbach. Teknik ini merupakan teknik yang sesuai untuk memeriksa konsistensi internal dalam sebuah tes karena koefisien konsistensi internal adalah indeks homogenitas isi dan kualitas item. Pengujian reliabilitas dilakukan dengan mengolah data-data pada program SPSS versi 16.0 for Windows. Hasil uji coba skala kecerdasan emosional dilakukan pada 156 siswa SMA di Medan dan kemudian diperoleh nilai reliabilitas $\alpha=.93$.

\section{Uji hipotesis}

Uji hipotesa menggunakan analisis statistik one way Anova, yaitu untuk menguji adanya perbedaan kecerdasan emosional siswa ditinjau dari jenis kegiatan ekstrakurikuler yang diikutinya. Seluruh proses pengolahan data penelitian dilakukan dengan menggunakan bantuan komputer program SPSS for windows 16.0 version. Alasan peneliti menggunakan metode ini karena hipotesis dalam penelitian ini bersifat komparatif maka menggunakan one way Anova dengan sampel yang tidak berhubungan maka menggunakan analisis yang bersifat independent.

\section{HASIL}

\section{Hasil utama}

Berdasarkan hasil analisis One Way Anova, $F(5,158)=58.58, p=001$. Dengan demikian dapat diambil kesimpulan bahwa $\mathrm{H}_{0}$ ditolak dan $\mathrm{H}_{\mathrm{a}}$ diterima yang menyatakan bahwa 
ada perbedaan kecerdasan emosional ditinjau dari jenis kegiatan ekstrakurikuler yang diikuti siswa.

Berdasarkan hasil analisa data diperoleh bahwa kelompok yang memiliki kecerdasan emosional paling tinggi adalah kelompok yang mengikuti jenis kegiatan ekstrakurikuler keterlibatan prososial, kemudian kelompok jenis kegiatan ekstrakurikuler pertunjukan seni, jenis kegiatan ekstrakurikuler keterlibatan sekolah, jenis kegiatan ekstrakurikuler kelompok akademik, dan jenis kegiatan ekstrakurikuler tim olahraga memiliki kecerdasan emosional paling rendah dari yang lainnya.

\section{Hasil tambahan}

Berdasarkan hasil One Way Anova pada hipotesis penelitian ini menunjukkan bahwa terdapat perbedaan pada aspek-aspek kecerdasan emosional ditinjau dari jenis kegiatan ekstrakurikuler yang diikuti siswa. Pada setiap aspek kecerdasan emosional, perbedaan mean ditemukan diantara 5 kelompok.

\section{DISKUSI}

Berdasarkan hasil analisa data diperoleh bahwa kelompok yang memiliki kecerdasan emosional paling tinggi adalah kelompok yang mengikuti jenis kegiatan ekstrakurikuler keterlibatan prososial, kemudian kelompok jenis kegiatan ekstrakurikuler pertunjukan seni, jenis kegiatan ekstrakurikuler keterlibatan sekolah, jenis kegiatan ekstrakurikuler kelompok akademik, dan jenis kegiatan ekstrakurikuler tim olahraga memiliki kecerdasan emosional paling rendah dari yang lainnya.

Berdasarkan hasil One Way Anova pada uji hipotesis penelitian ini menunjukkan bahwa terdapat perbedaan pada aspek-aspek kecerdasan emosional ditinjau dari jenis kegiatan ekstrakurikuler yang diikuti siswa. Pada setiap aspek kecerdasan emosional, perbedaan mean juga ditemukan diantara lima kelompok.

Adanya perbedaan kecerdasan emosional berdasarkan jenis kegiatan ekstrakurikuler dapat disebabkan oleh beberapa hal. Gibson (2005) mengungkapkan bahwa di dalam suatu organisasi terdapat berbagai macam proses, diantaranya proses komunikasi, proses pengambilan keputusan, proses evaluasi prestasi, dan proses sosialisasi serta karir. Semua proses ini erat kaitannya dengan hubungan antar manusia dan interaksinya.

Berdasarkan hasil analisa data diperoleh bahwa kelompok yang memiliki kecerdasan emosional paling tinggi adalah kelompok yang mengikuti jenis kegiatan ekstrakurikuler keterlibatan prososial. Pada aspek mengelola emosi dan mengenali emosi orang lain, jenis kegiatan ekstrakurikuler keterlibatan prososial juga memperoleh mean yang paling tinggi dari jenis kegiatan ekstrakurikuler lainnya. Hal ini sesuai dengan yang dinyatakan Mahoney (2005) bahwa jenis kegiatan ekstrakurikuler keterlibatan prososial lebih berfokus untuk mengembangkan kecerdasan emosional dan menciptakan lingkungan yang efektif, harmonis terhadap diri sendiri dan terhadap semua pihak. Kegiatan ini dimaksudkan agar siswa terbiasa berinteraksi dan saling kerjasama dengan orang lain. Selain itu kegiatan terebut dapat menumbuhkan kecerdasan emosi siswa karena dengan kegiatan tersebut anak akan menghargai orang lain, belajar mengendalikan emosi, berempati dengan orang lain, saling tolong menolong dan bekerjasama dalam mengerjakan tugas.

Berdasarkan hasil analisa data diperoleh bahwa kelompok yang memiliki kecerdasan emosional paling rendah adalah kelompok yang mengikuti jenis kegiatan ekstrakurikuler tim olahraga. Pada aspek mengenali emosi diri, mengelola emosi, dan memotivasi diri sendiri, jenis 
kegiatan ekstrakurikuler tim olahraga juga memperoleh mean yang paling rendah dari jenis kegiatan ekstrakurikuler lainnya. Hal ini tidak sesuai dengan yang dikemukakan Brooks (2000) bahwa siswa yang mengikuti ekstrakurikuler olahraga tidak hanya dapat mengembangkan keterampilan, tetapi mereka juga belajar untuk menghormati otoritas, belajar untuk menghadapi tantangan baru, dan menikmati kebersamaan dengan teman. Kegiatan olahraga tidak hanya baik untuk fisik tetapi juga meningkatkan emosional siswa. Berolahraga dapat mengurangi kecemasan dan depresi, mengurangi tekanan darah, dan meningkatkan harga diri. Anak-anak yang berolahraga lebih percaya diri, mengurangi ketidakhadiran di sekolah, dan biasanya mendapatkan nilai yang lebih baik.

Menurut Mahoney (2005), kegiatan ekstrakurikuler dapat menimbulkan respon kecerdasan emosional yang berbeda. Dalam hal ini respon kecerdasan emosional dapat bersifat positif (enjoyment) atau negatif (stress). Mahoney (2005) membagi sumber respon tersebut dalam 3 kategori yaitu : intrapersonal, situational dan significant others. Intrapersonal meliputi kepribadian siswa dan bagian psikologisnya. Pada situational, seperti menang atau kalah saat mengikuti kompetisi. Lalu pada significant others, meliputi hubungan dengan orang tua, pembina, dan teman-teman.

Penelitian Mahoney (2005) pada remaja putri berumur 14 tahun yang mengikuti ekstrakurikuler olahraga bidang olahraga, menunjukkan kecerdasan emosional remaja tersebut dapat berubah tergantung dari pengalaman yang didapatnya. Kecerdasan emosional yang rendah atau negatif ditemukan ketika remaja tersebut merasakan stres saat dia harus menguasai teknik olahraga yang sempurna (intrapersonal), saat mengikuti suatu kompetisi (situational) serta disaat mendengar penilaian yang negatif dari pembimbingnya (significant others). Tetapi kecerdasan emosional remaja tersebut dinilai mengalami peningkatan atau positif saat dia senang karena berhasil menguasai teknik yang susah (intrapersonal), menang dalam sebuah kompetisi (situational) dan mendapatkan pujian serta teman - teman baru disaat berkompetisi (significant others). Ketiga respon emosional diatas dapat mengubah 4 komponen dasar seseorang, yaitu sosial, kognitif, motor dan fisik. Semua komponen tersebut dapat berubah sejalan dengan respon emosional yang diterima. Hal ini dapat berhubungan disaat seseorang sedang mengikuti ekstrakurikuler.

Mahoney (2005) dalam penelitiannya menilai adanya pengaruh persepsi seorang siswa yang mengikuti ektrakurikuler mengarah ke respon emosionalnya dan mempengaruhi kecerdasan emosional dalam hal ini seperti motivasi. Seorang siswa yang memiliki sebuah persepsi yang mengarah ke respon emosional positif (enjoyment) atau respon emosional negatif (stress), dapat mengubah motivasinya. Contoh, seorang siswa yang memiliki persepsi bahwa olahraga itu baik untuk kesehatan, maka akan timbul respon emosional positif dan motivasi yang tinggi sehingga muncul semangat untuk ikut ekstrakurikuler bidang olah raga, kerja keras dalam mencapai sesuatu dan pantang menyerah. Contoh lain, seseorang siswa yang memiliki persepsi bahwa belajar disaat ektrakurikuler hanya menghabiskan waktu dan membosankan, maka timbul respon negatif yang mengarah ke penurunan motivasi sehingga terjadi kemalasan, tidak semangat dan stres. Stres yang berlanjut dapat menimbulkan sifat menghindar, seperti tidak lagi mengikuti kegiatan ekstrakurikuler.

Selain dari kegiatan ekstrakurikuler, kegiatan lain yang siswa ikuti di luar sekolah seperti mengikuti les tambahan untuk kegiatan akademik, seni dan olahraga juga mempengaruhi kecerdasan emosional. Menurut Cooper (2000), proses yang terjadi di dalam kegiatan di luar sekolah mendukung perkembangan kecerdasan emosi seseorang karena siswa dapat belajar berkomunikasi dengan orang lain dengan baik serta mampu mengembangkan potensi yang 
dimiliki oleh anak-anak. Proses inilah yang mendukung terbentuknya suatu empati dari tiap siswa, sehingga empati terhadap apa yang dirasakan orang lain meningkat. Kepekaan terhadap emosi orang lain ini yang mendorong seseorang untuk mengasihi sepenuh hati dan berusaha menolongnya Seseorang yang mempunyai kecerdasan sosial yang baik akan mempunyai banyak teman, pandai berkomunikasi, mudah beradaptasi dalam sebuah lingkungan sosial, dan hidupnya bisa bermanfaat tidak hanya untuk dirinya sendiri, tetapi juga bagi orang lain. Sungguh, kemampuan-yang di antaranya-seperti itulah yang sangat dibutuhkan oleh anak kita agar kelak lebih mudah dalam menghadapi tantangan kehidupan di zaman yang semakin ketat dengan persaingan. Dengan demikian, semoga anak-anak kita lebih mudah dalam meraih kesuksesan. (Mahoney, 2005).

Faktor-faktor yang mempengaruhi kecerdasan emosional seseorang diungkapkan oleh Goleman (2002) bahwa faktor-faktornya terdiri dari faktor internal dan faktor eksternal dari seseorang. Faktor internal mencakup struktur dari otak manusia. Sedangkan untuk faktor eksternal mencakup faktor keluarga dan non keluarga. Faktor keluarga berhubungan erat dengan sifat orangtua yang diidentifikasi kemudian diinternalisasi oleh anak, sehingga kecerdasan emosional dipengaruhi juga oleh hal ini. Untuk faktor non keluarga terdiri dari lingkungan masyarakat, lingkungan pendidikan, dan bisa juga karena pengalaman sebelumnya, yaitu pelatihan asertivitas yang didapatkan sebelumnya.

Kecerdasan emosional yang dimaksudkan dalam penelitian ini diambil dari pendapat Goleman (2002) yakni kemampuan yang dimiliki seseorang dalam memotivasi diri untuk mencapai tujuan, memiliki ketahanan dalam menghadapi kegagalan, sanggup mengendalikan emosi diri, serta dapat memahami perasaan orang lain. Dari aspek-aspek tersebut, dapat digunakan sebagai penilaian terhadap tingkatan kecerdasan emosional seseorang.

\section{Saran}

\section{Saran teoritis}

Bagi peneliti selanjutnya yang tertarik untuk melakukan penelitian tentang kecerdasan emosional pada siswa yang mengikuti kegiatan ekstrakurikuler disarankan agar mempertimbangkan faktor-faktor yang mempengaruhi kecerdasan emosional seperti lingkungan keluarga, tempat tinggal, lingkungan sekolah dan kegiatan lain yang diikuti siswa di luar sekolah.

\section{Saran Praktis}

Para pembina jenis kegiatan ekstrakurikuler harus memperhatikan seluruh aspek-aspek yang dapat meningkatkan kecerdasan emosional siswa, karena kegiatan ekstrakurikuler jenis apapun sebenarnya dapat meningkatkan kecerdasan emosional siswa menjadi lebih baik lagi.

Dari hasil penelitian, jenis ekstrakurikuler tim olahraga memperoleh nilai yang rendah dari yang lainnya. Oleh karena itu, disarankan kepada Pembina ekstrakurikuler olahraga untuk memperbaiki cara pembinaan pada siswa agar tidak hanya mengutamakan kemampuan fisik saja, karena ekstrakurikuler olahraga juga bertujuan untuk meningkatkan kecerdasan emosional siswa.

\section{DAFTAR PUSTAKA}

Ashron, L. J. (2009). The impact of extracurricular participation on the first year college experience of freshman in a college of agriculture. http://etd.lib.ttu.edu/theses/available/etd-04032009105653/unrestricted /Ashorn_Laura_Thesis.pdf.

Azwar, S. (2000). reliabilitas dan validitas. Yogyakarta: Pustaka Belajar Azwar, S. (2000). Penyusunan Skala Psikologi. Yogyakarta: Pustaka Belajar 
Blomfield, C. (2010). Australian Adolescents' Extracurricular Activity Participation and Positive Development: Is the Relationship Mediated by Peer Attributes. Australian Journal of Educational and Developmental Psychology, 10, 108-122. http://www. collegiateassessment.com/acarticle2.pdf.

Brooks, A. L. (2000). A study of the relationship between the increased growth and development of elementary students when participating in extracurricular activities and the adaptations that parents, schools, and communities make to meet these after school. http://www.uwstout.edu/content/lib/thesis/2000/2000brooksa.pdf.

Cahyaningtyas, A. (2010). Perbedaan kecerdasan emosional berdasarkan status keikutsertaan dalam organisasi ekstrakurikuler pada mahasiswa d iv kebidanan. http://digilib.uns.ac.id/ upload/dokumen/149081608 201001371.pdf. Tanggal akses: 06 Maret 2011.

Cooper, R.K., \& Sawaf, A. (1999). Executive EI: Kecerdasan emosional dalam kepemimpinan dan organisasi. Jakarta: Gramedia Pustaka Utama.

Deniz, M.E. (2008). A comparison of scouts' emotional intelligence levels with regards to age and gender variables: a cross-cultural study. http://ilkogretimonline.org.tr/vol7say2/v7s2m12.pdf.

Depdiknas. (2005). Kamus Besar Bahasa Indonesia. Jakarta: Balai Pustaka.

Depdiknas (2003). Undang-undang republik indonesia nomor 20 tahun 2003 tentang sistem pendidikan nasional. Jakarta: B .P. Dharma Bhakti.

Depdiknas. (2003). Petunjuk teknis pelaksanaan pengembangan diri pada sekolah menengah. Jakarta: B. P. Dharma Bhakti.

Diastuti. M. (2006). Pola Pengambilan Keputusan Karier Siswa Berbakat Intelektual. Journal Anima, 22(1), 58-73. http://www.collegiateassessment.com/acarticle2.pdf. Tanggal akses: 06 Maret 2011.

Fernandez, P. (2008). Emotional intelligence in education. Electronic Journal of Research in Educational Psychology, 6(15). [On-line] http://www.srcd.org/press/mahoney.pdf.

Fruh, J.M. (2005). The correlation of emotional intelligence, academic achievement and clinical performance in undergraduate athletic training students. http://www.oregonpdf.org/pdf/PE4773Fruh(19-1).pdf. Tanggal akses: 03 Maret 2011.

Fujita, K. (2005). The effects of extracurricular activities on the academic. http://ilkogretimonline.org.tr/vol7say2/v7s2m12.pdf.

Goleman, D. (2002). Emotional intelligence (terjemahan). Jakarta: PT. Gramedia Pustaka Utama.

Hapsari, U. (2010). Hubungan antara minat mengikuti kegiatan Ekstrakurikuler dengan intense Delinkuensi remaja pada siswa SMK di kota Semarang. Jurnal Ilmiah Psikologi Terapan. 6(7).

Lutan, R. (2000). Pengelolaan interaksi belajar mengajar intrakurikuler dan ekstrakurikuler. Jakarta: Universitas Terbuka

Mahoney, J. (2005). Organized Activities as Context of Development: Extracurricular Activities, After School and Community Programs. New York: Lawrence Erlbaum.

Mahoney, J. (2006). Organized Activity Participation, Positive Youth Development and the Over-Scheduling Hypothesis. http://www.srcd.org/press/mahoney.pdf.

Maryati, I. (2008). Hubungan Antara Kecerdasan Emosi dan Keyakinan Diri dengan Kreatifitas pada Siswa Akselerasi. http://etd.eprints.ums.ac.id/3693/1/F100040097.pdf.

Nurdin. (2009). Pengaruh Kecerdasan Emosional Terhadap Penyesuaian Sosial Siswa Di Sekolah. Jurnal Administrasi Pendidikan, 9(2). http://www.kon.org/urc/v5/fujita.html. 
Prawitasari, J. E. (2003). Psikologi klinis: Dari terapan mikro ke makro. Anima, Indonesian Psychological Journal, 18(3), 215-228. http://etd.lib.ttu.edu/theses/available/etd-04032009105653/unrestricted /Ashorn_Laura_Thesis.pdf.

Rubin, R.S. (2002). Using Extracurricular Activity As An Indicator Of Interpersonal Skill : Prudent Evaluation Or Recruiting Malpractice? http://www.collegiateassessment.com/acarticle2.pdf.

Sanchezruiz, M.J. (2010). Trait emotional intelligence profiles of students from different university faculties. Australian Journal of Psychology, 62(1), 51-57.

Sayette, M. (2010). Insider guide to graduate programs in clinical and counseling psychology. New York: The Guildford Press

Sudjana, N. (2002). Dasar-dasar proses belajar mengajar, Bandung: Sinar Baru Algensindo.

Widyasari, C. (2008). Program Pengembangan Kompetensi Sosial untuk Remaja Siswa SMA di Kelas Akselerasi. Jurnal Provitae. Volume.2, no 2. [On-line] http://etd.lib.ttu.edu/theses/available/etd-04032009-105653/unres tricted/Ashorn_Laura_Thesis.pdf. Tanggal akses: 06 Maret 2011.

Yue, Y. (2009). On the Problems Existed in Chinese Art Education and the Way Out. International Education studies http://www.collegiateassessment.com/acarticle2.pdf. 